\title{
Anatomy of male and female reproductive organs of stink bugs pests (Pentatomidae: Heteroptera) from soybean and rice crops
}

\author{
Vinícius Albano Araújo ${ }^{1 *}$, Tito Bacca ${ }^{2}$ \& Lucimar Gomes Dias ${ }^{3,4}$ \\ ${ }^{1}$ Universidade Federal do Rio de Janeiro, Instituto de Biodiversidade e Sustentabilidade, Macaé, RJ, Brasil. \\ ${ }^{2}$ Universidad del Tolima, Facultad de Ingeniería Agronómica, Ibagué, Tolima, Colombia. \\ ${ }^{3}$ Universidad de Caldas, Caldas, Facultad de Ciencias Exactas y Naturales, Departamento de Ciencias Biológicas, \\ Colombia. \\ ${ }^{4}$ Universidad de Caldas, Grupo de investigación Bionat, Caldas, Colombia. \\ *Corresponding author: Vinícius Albano Araújo, e-mail: vialbano@gmail.com
}

ARAÚJO, V., BACCA, T., DIAS, L. Anatomy of male and female reproductive organs of stink bugs pests (Pentatomidae: Heteroptera) from soybean and rice crops. Biota Neotropica 20(4): e20201045. https://doi.org/10.1590/1676-0611-BN-2020-1045

\begin{abstract}
Pentatomidae comprises a diverse group of stink bugs widely distributed in the Neotropical region. Many species are phytophagous and cause injuries to plants, and can thus be defined as agricultural pests. In this study, the anatomy of the female and male reproductive tracts of three important agricultural pests in Colombia is described: Piezodorus guildinii Westwood, 1837 and Chinavia ubica Rolston 1983, found on soybeans, and Oebalus insularis Stål, 1872, found in rice crops. For that, light microscopy techniques were used. The anatomy of the reproductive tract of sexually mature males of the three species studied consisted of a pair of testes, vas deferens, seminal vesicles, ejaculatory bulb, an ejaculatory duct that opens into an aedeagus, and paired accessory glands. The reproductive tract of females consisted of a pair of ovaries, each with seven telotrophic-meroistic ovarioles, a pair of lateral oviducts, common oviduct, spermatheca, and a genital chamber. Telotrophic ovarioles were comprised of terminal filament, tropharium, vitellarium, and pedicel. Differences in size, color, and position of structures along the reproductive tract were observed between the species examined. Reproductive biology of insects provides informative characters for behavioral and evolutionary studies, as well as useful data for pest control strategies.
\end{abstract}

Keywords: reproductive morphology, Heteroptera, testes, ovaries.

\section{Anatomia dos órgãos reprodutivos em machos e fêmeas de percevejos praga (Pentatomidae: Heteroptera) das culturas de soja e arroz}

Resumo: Pentatomidae compreende um diverso grupo de percevejos amplamente distribuídos na região Neotropical. Muitas espécies são fitófagas e causam algum tipo de injúria em plantas, podendo se configurar como pragas agrícolas. Neste trabalho, descrevemos a anatomia do trato reprodutor de machos e fêmeas em três importantes pragas agrícolas da Colômbia: Piezodorus guildinii (Westwood 1837) e Chinavia ubica (Rolston 1983) na cultura de soja e Oebalus insularis (Stål 1872) na cultura do arroz. Para isto, foram utilizadas técnicas de microscopia de luz. A anatomia do trato reprodutor em machos sexualmente maduros nas três espécies consistiu de um par testículos, vasos deferentes, vesículas seminais, bulbo ejaculatório, um ducto ejaculatório que se abre em um aedeagus e glândulas acessórias pareadas. O trato reprodutor das fêmeas consistiu de um par de ovários, cada um com sete ovaríolos telotróficos-meroísticos, um par de ovidutos laterais, uma espermateca e a câmara genital. Os ovaríolos telotróficos possuíam quatro diferentes regiões: filamento terminal, germário, vitelário e pedicelo. As diferenças entre as espécies foram observadas no tamanho, cor e posição das estruturas ao logo do trato reprodutivo. A biologia reprodutiva de insetos gera caracteres que fornecem informações para trabalhos envolvendo evolução, comportamento e estratégias de controle de pragas.

Palavras-chave: morfologia reprodutiva, Heteroptera, testículos, ovários. 


\section{Introduction}

Stink bugs (Pentatomidae) comprise the fourth largest Heteroptera family, with approximately 4,700 species described (Grazia et al. 2015). Most pentatomids are phytophagous and generalists, feeding on sap and other plant-produced substances (Grazia et al. 2012). Pentatomids have piercing sucking mouthparts, and most of them are phytophagous, including several species that are severe pests of agricultural crops. However, some species, particularly in the subfamily Asopinae, are predatory and may be considered beneficial. Phytophagous species feed on a wide range of food resources and have an extensive global distribution, which leads many of them to be defined as important agricultural pests (Panizzi et al. 2000, Grazia et al. 2012, Li et al. 2017, Lucini et al. 2020).

In the Neotropical region, pentatomids are one of the major insect groups that cause damage to different crops (McPherson \& MacPherson 2000, Panizzi et al. 2000, Smaniotto \& Panizzi 2015). In crops such as soybeans and rice, these stink bugs can cause physiological changes in plants, affecting their development, flowering, fruiting, and therefore, crop performance and grain and seed quality (McPherson \& McPherson 2000, Panizzi et al. 2000, Karban \& Agrawal 2002, Possebom et al. 2020).

The stink bug Piezodorus guildinii (Westwood 1837) is widely distributed in the Neotropical region and is one of the most harmful pests to soybean crops in the Americas (Panizzi \& Slansky 1985). If the attack strikes during grain development and pod filling, major losses might occur (Galileo \& Heinrichs 1978). Chinavia ubica Rolston, 1983 is a minor pest of soybean crop (Silva et al. 2015); however, Chinavia Orian, 1965 - senior synonym of Acrosternum Fieber, 1860 - is polyphagous and causes damage to several crops, such as vegetables and fruits (Panizzi et al. 2000). The stink bug Oebalus insularis Stål, 1872 is a harmful pest to rice crops and is very common in Colombia, Central America, and the Caribbean. This species is responsible for significant economic losses in these regions due to its ability to suck grains during development, thus affecting grain amount and quality, reducing production by more than 50\% (Gutiérrez et al. 1985, Rodriguez et al. 2006).

The comparative morphology of the reproductive tract in male and female stink bugs has already been described in several Pentatomidae species, and males generally exhibit a pair of testes, deferent ducts, ejaculatory bulb complex, paired accessory glands, and an ejaculatory duct (Pendergrast 1956, Adams 2001, Lemos et al. 2001, Candan et al. 2010, 2015, Araújo et al. 2011, 2020, Özyurt et al. 2013a, 2013b, 2014, 2015, Cremonez et al. 2017). On the other hand, females exhibit a pair of ovaries connected to the lateral oviducts by the pedicels of ovarioles, a common oviduct, and a spermatheca (Lemos et al. 2005, Candan et al. 2010, 2014, 2015, Cremonez et al. 2017). Insect ovaries and ovarioles can be classified into two types according to the presence (or absence) of nurse cells. In panoistic ovaries, nurse cells are absent, usually observed in more basal groups. In meroistic ovaries, the nurse cells are associated with the development of eggs. There are two types of meroistic ovaries, the polytrophic ovariole ones, in which oocytes are closely associated with the nurse cells, and the telotrophic ones, typical of Hemiptera and some Coleoptera, in which the nurse cells are at the apex of the ovary, in the germinal region (Bonhag 1958). These studies indicate that there are interspecific differences in reproductive anatomy regarding size or number of structures, the absence of any of them, and their color or position along the reproductive tract. Hence, the anatomy of these insects provides important characters for systematics and expands knowledge on the reproductive biology of the group.
The anatomy of both male and female reproductive tracts of three important pest insects was described in the present study: $P$. guildinii and C. ubica, found on soybeans, and $O$. insularis, found in rice crops, in order to provide knowledge on their reproductive biology and new data to be used in the systematics of these important agricultural pests.

\section{Materials and Methods}

\section{Insects}

Ten individuals of each sex of the following species were actively collected with the aid of entomological nets from crops located in the municipality of Armero-Guayabal, Tolima, Colombia (5'09'72'N 7454'19"O): Oebalus insularis Stål, 1872 on rice, Chinavia ubica Rolston, 1983 and Piezodorus guildinii Westwood, 1837 on soybeans (Fig. 1). For species identification, the original descriptions (Sailer, 1944; Rolston, 1983) and specific taxonomic keys for this group were used (Schwertner \& Grazia 2007; Grazia et al. 2015).
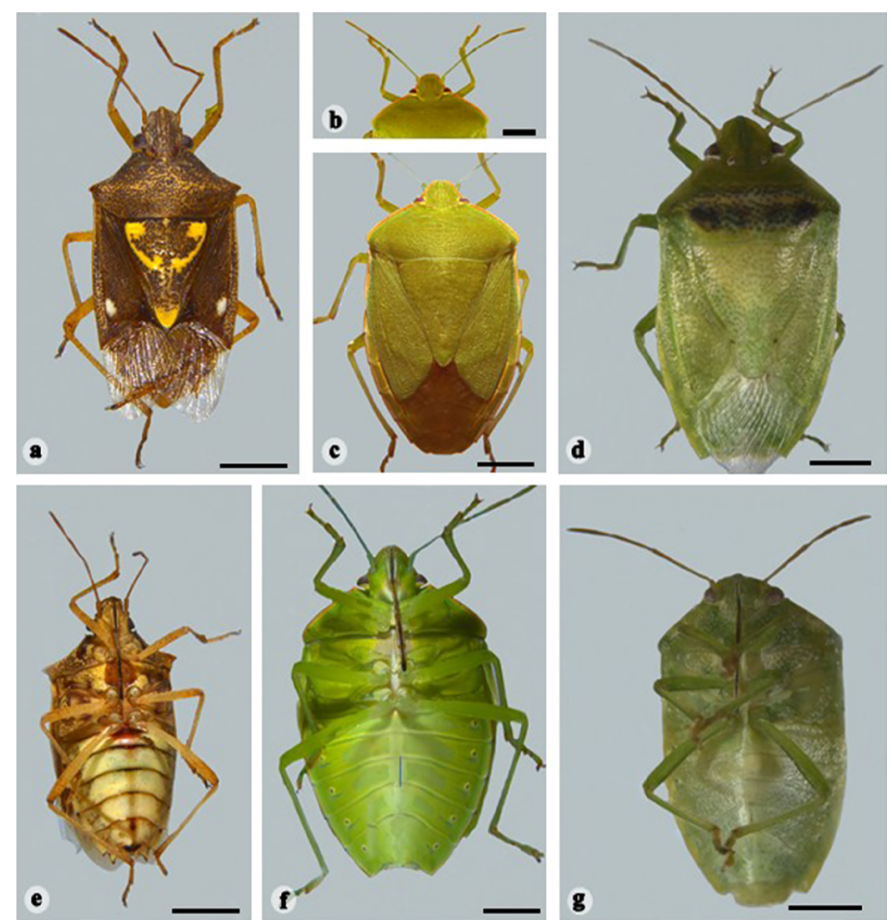

Figure 1. A-D. Habitus of dorsal and ventral areas of Oebalus insularis (A and E), Chinavia ubica (B-C and F), and Piezodorus guildinii adults (D and G). Bars: $2 \mathrm{~mm}$.

\section{Light microscopy}

Insects were cryoanesthetized at $-5{ }^{\circ} \mathrm{C}$ for $10 \mathrm{~min}$ and their reproductive tracts were dissected in $0.1 \mathrm{M}$ sodium chloride. For anatomical analysis, the reproductive tracts, freshly fixed in $2.5 \%$ glutaraldehyde buffered with sodium cacodylate, $0.1 \mathrm{M}, \mathrm{pH} 7.2$ for a few minutes, were placed on histological slides with drops of the same buffer. Their reproductive tracts were photographed unstained using a Leica M205 C light microscope and a Leica MC 170 HD digital camera. 
All measurements were performed using Image Pro-Plus (Media Cybernetcs), and lengths were expressed as the mean value of ten dissected individuals from each species analyzed. Species measurements were compared using ANOVA and Tukey's test. Data were analyzed using Generalized Linear Models (GLM) in the R software (R Core Team 2016).

\section{Results}

The male reproductive tract of the three studied species consists of a pair of testes, a pair of vas deferens, a pair of ectodermal sacs, a complex ejaculatory bulb, accessory glands, and ejaculatory duct
(Figures 2a, 3a, 4a). Each testis is comprised of testicular follicles, which are usually enclosed in a common sheath. Six testicular follicles were observed in $O$. insularis (Figure $2 \mathrm{~b}$ ). The testes and deferent ducts are externally covered by a red-pigmented peritoneal sheath (Figures 2a-d, 3a-b, 4a-c). In P. guildinii, the basal region of the deferent ducts exhibited a yellowish peritoneal sheath (Figures $3 \mathrm{a}, 3 \mathrm{c}$ ).

Testis length $(\mathrm{F} 3 ; 45=7.08 ; \mathrm{P}=0.001)$, testis width $(\mathrm{F} 3 ; 45=$ $19.65 ; \mathrm{P}=0.003)$, and vas deferens length $(\mathrm{F} 3 ; 45=13.65 ; \mathrm{P}=0.002)$ varied significantly between the sampled species (Table 1 and Figures $2 \mathrm{a}, 3 \mathrm{a}-\mathrm{b}, 4 \mathrm{a}-\mathrm{b})$. The vas deferens did not exhibit an enlarged and differentiated region along its length to be distinguished as a seminal vesicle (Figures 2a, 3a, 4a).
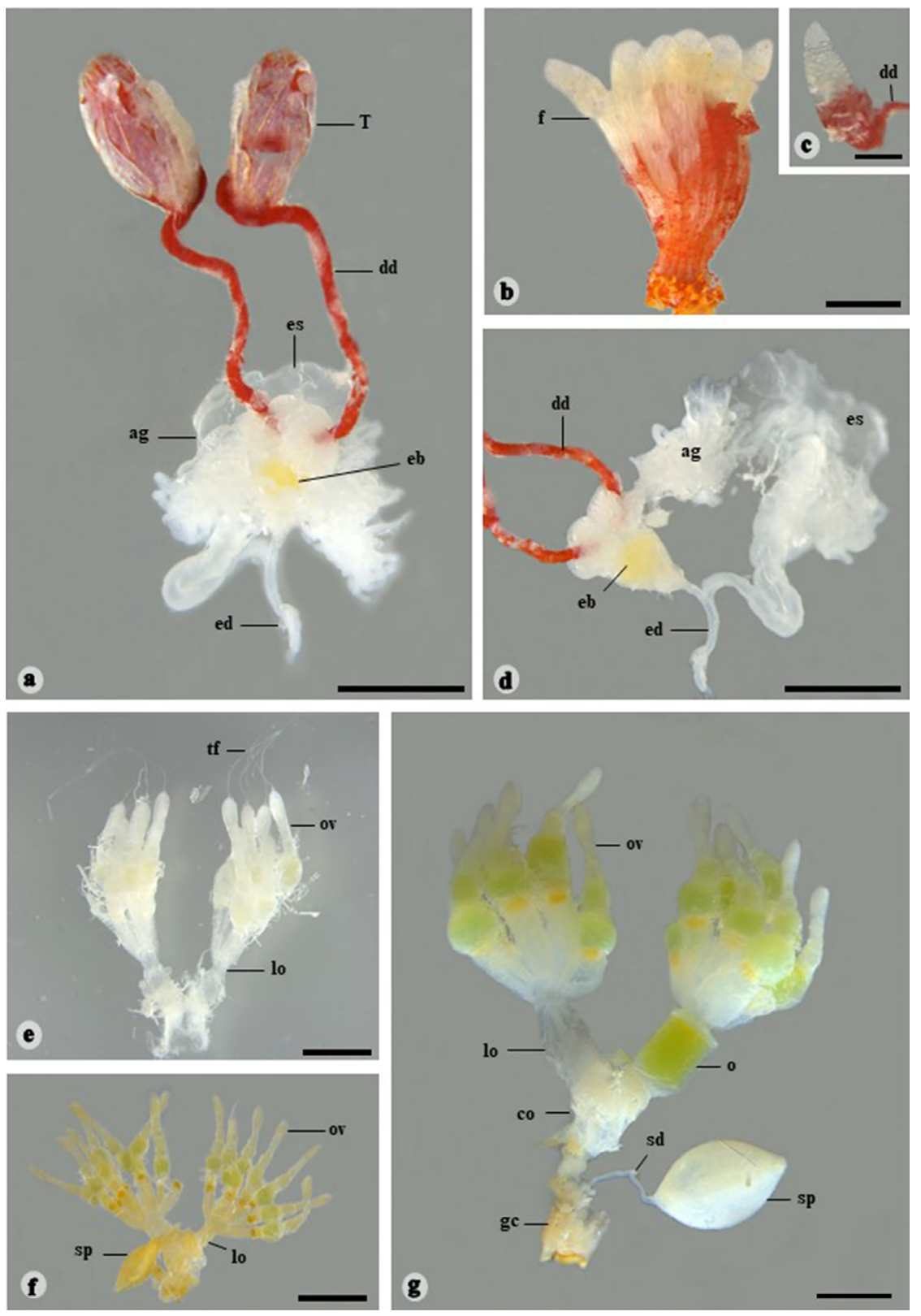

Figure 2. Photomicrograph of the anatomy of the male and female reproductive tract of Oebalus insularis. A. Male reproductive tract showing the testis $(\mathrm{T})$, deferent ducts (dd), ectodermal sac (es), ejaculatory bulb (eb), accessory glands (ag), and ejaculatory duct (ed). B. Testis exhibiting six testicular follicles. C. Detail of a single testicular follicle. D. Region of the reproductive tract showing deferent ducts, accessory glands, ectodermal sac, ejaculatory bulb, and ejaculatory duct. E-G. Female reproductive tract with ovarioles (ov), terminal filaments (tf), lateral oviducts (lo), common oviduct (co), spermatheca (sp), spermathecal duct (sd), oocytes (o), and genital chamber (gc). Bars $=\mathrm{A}-\mathrm{C}$ and $\mathrm{D}-\mathrm{G}=1 \mathrm{~mm} ; \mathrm{C}=2 \mathrm{~mm}$. 

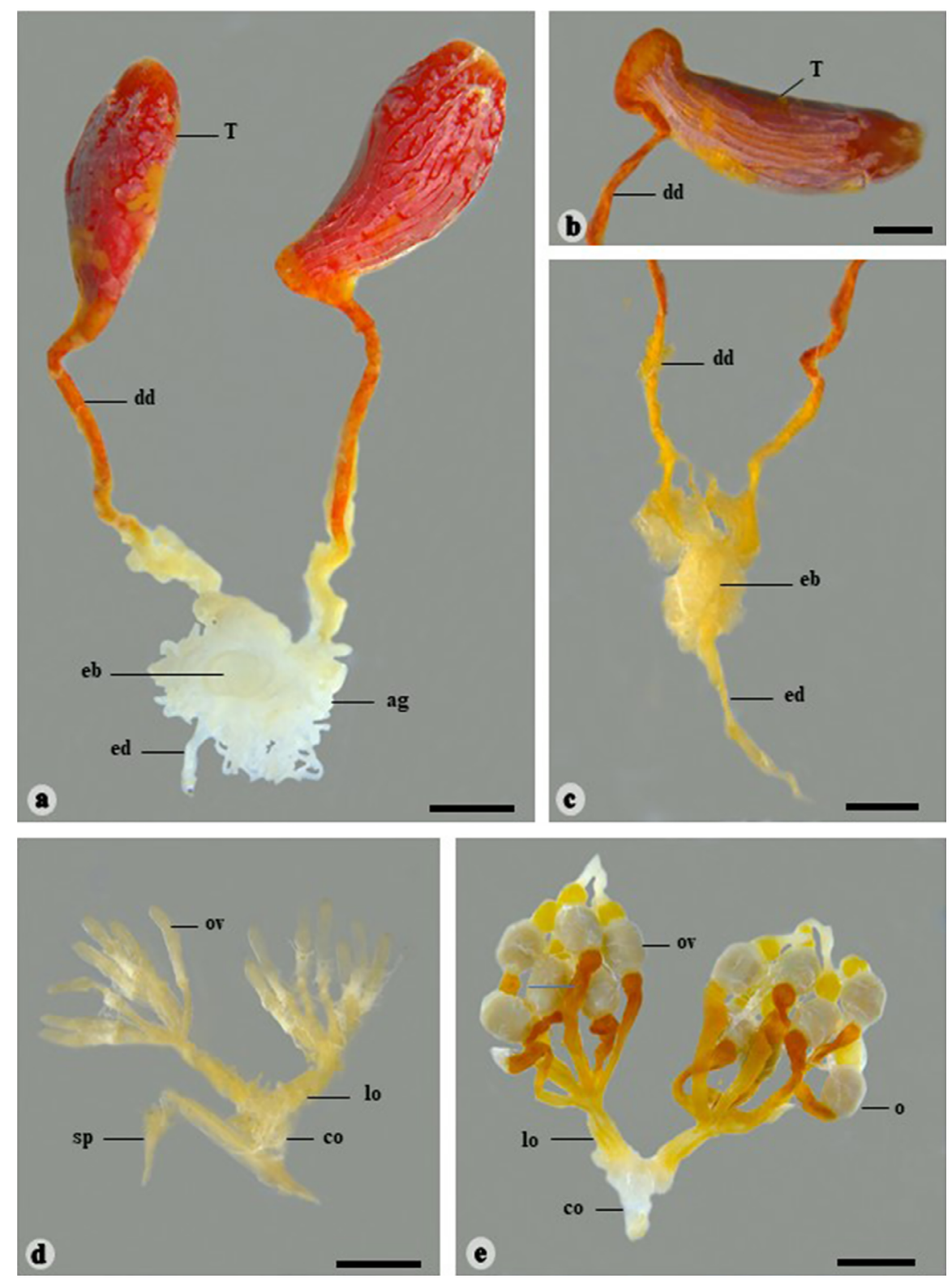

Figure 3. Photomicrograph of the anatomy of the male and female reproductive tracts of Chinavia ubica. A. Male reproductive tract showing the testis (T), deferent ducts (dd), ejaculatory bulb (eb), accessory glands (ag), and ejaculatory duct (ed). B. One testis. C. Region of the reproductive tract showing deferent ducts, ejaculatory bulb, and ejaculatory duct. D-E. Female reproductive tract showing ovarioles (ov), lateral oviducts (lo), common oviduct (co), spermatheca (sp), and oocytes (o). Bars $=\mathrm{A}-\mathrm{C}=1 \mathrm{~mm}$; D-E $=2 \mathrm{~mm}$.

Tubular accessory glands were observed in all three species studied (Figures 2a, 3a, 4a). In $O$. insularis, tubular accessory glands and ectodermal sac open in a single duct that converges into the ejaculatory duct near the proximal portion of the ejaculatory bulb (Figure 2d). This species has a yellow pear-shaped ejaculatory bulb (Figures 2a, 2d). In C. ubica, tubular accessory glands open at the base of the deferent ducts, immediately above the ejaculatory bulb, which was ovoid and transparent in this species (Figures 3c-d). In $P$. guildinii, tubular accessory glands and the ectodermal sac open in the region of a greenish oval-shaped ejaculatory bulb (Figure 4a-b). The ejaculatory duct of this species was long and folded (Figures 4a, 4c).
The female reproductive tract of the three studied species is formed by a pair of ovaries, each one with seven telotrophic-meroistic ovarioles connected by a pair of lateral oviducts, a spermatheca, a common oviduct, and a vagina that opens into the genital chamber (Figures 2e, $3 \mathrm{e}, 4 \mathrm{c})$. The telotrophic-meroistic ovarioles developed synchronously and exhibited four different regions: terminal filament, tropharium, vitellarium, and pedicel (Figures 2e-h).

$O$. insularis oocytes had greenish coloration and a well-developed spermatheca connecting to the common oviduct through a spermathecal duct (Figures 2e-h). Oocytes are white in C. ubica (Figure 3e) and yellowish in $P$. guildinii, with an elongated spermatheca and a brown spermathecal duct (Figures 4d-e). In all three species, female adults exhibited structural changes in the reproductive tract during oogenesis (Figures 2e-h, 3e, 4c-d). 

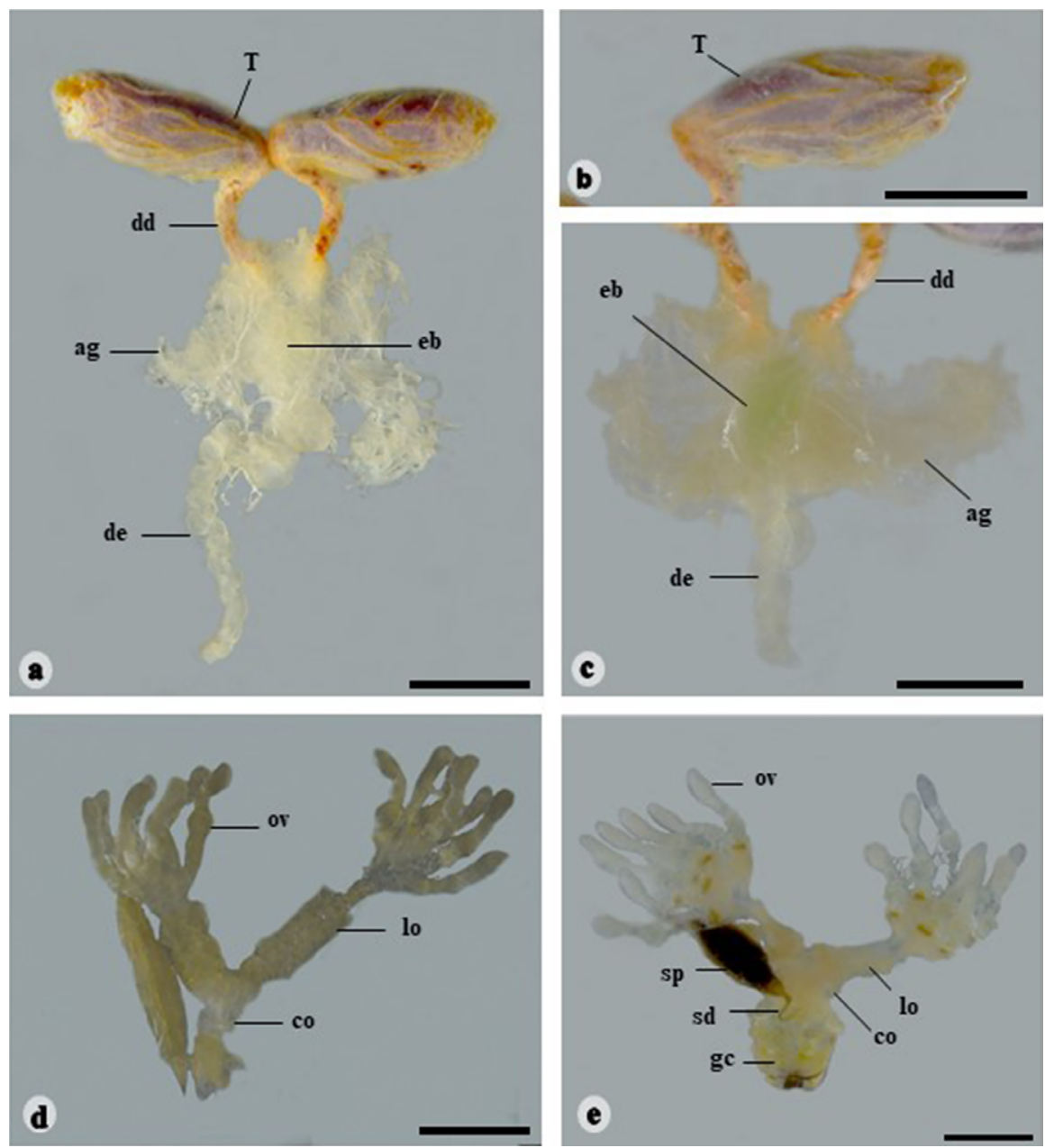

Figure 4. Photomicrograph of the anatomy of the male and female reproductive tracts of Piezodorus guildinii. A. Male reproductive tract showing the testis (T), deferent ducts (dd), ejaculatory bulb (eb), accessory glands (ag), and ejaculatory duct (ed). B. Testis. C. Region of the reproductive tract showing deferent ducts, accessory glands, ejaculatory bulb, and ejaculatory duct. D-E. Female reproductive tract showing ovarioles (ov), lateral oviducts (lo), common oviduct (co), spermatheca (sp), and genital chamber (gc). Bars $=1 \mathrm{~mm}$.

Table 1. Averages measurements of total body length and width $(\mathrm{mm})$ of testis, length of vas deferens and ratio of length of vas deferens to body in males of Oebalus insularis, Chinavia ubica and Piezodorus guildinii $(\mathrm{n}=10)$.

\begin{tabular}{lccccc}
\hline \multicolumn{1}{c}{ Species } & $\begin{array}{c}\text { Total body length } \\
(\mathbf{m m})\end{array}$ & $\begin{array}{c}\text { Testis length } \\
(\mathbf{m m})\end{array}$ & $\begin{array}{c}\text { Testis width } \\
(\mathbf{m m})\end{array}$ & $\begin{array}{c}\text { Vas deferens length } \\
(\mathbf{m m})\end{array}$ & $\begin{array}{c}\text { Vas deferens / Total } \\
\text { width }(\mathbf{m m})\end{array}$ \\
\hline Oebalus insularis Stal, 1872 & $7,4 \pm 0,311$ & $1.05 \pm 0,187$ & $0.56 \pm 0,034$ & $1,86 \pm 0,222$ & 0,25 \\
Chinavia ubica Rolston, 1983 & $13,4 \pm 0,287$ & $3.03 \pm 0,293$ & $1.36 \pm 0,067$ & $4,72 \pm 0,125$ & 0,35 \\
Piezodorus guildinii Westwood, 1837 & $8,9 \pm 0,075$ & $1.48 \pm 0,122$ & $0.67 \pm 0,124$ & $0,89 \pm 0,328$ & 0,1 \\
\hline
\end{tabular}

\section{Discussion}

The anatomy of the male reproductive tract maintains a general pattern in Pentatomidae, with some differences in size, shape, color, and location of structures (Pendergrast 1956, Adams 2001, Lemos et al. 2005, Rodrigues-Agna et al. 2008, Esquivel et al. 2009, Kaur \& Patial 2012, 2016, Özyurt et al. 2013a, 2014, 2015, Jyoti et al. 2015, Araújo et al. 2020).

Among Pentatomidae, the number of testicular follicles can vary from three, e.g. in Aeliomorpha lineaticollis Westwood, 1837 (Kaur \& Patial 2016), to seven, e.g. in Apodiphus amygdali Germar, 1817 (Ozyurt et al. 2014) and Eurydema ventralis Kolenati, 1846 (Ozyurt et al. 2015).
Six testicular follicles were observed in Oebalus insularis Stål, 1872, as well as in Nezara viridula Linnaeus, 1758 (Esquivel et al. 2009), Halys dentatus Fabricius, 1775 (Jyoti et al. 2015), and Podisus nigrispinus Dallas, 1851 (Lemos et al. 2005) - ranging from 4 to 6 follicles. Furthermore, the presence of four follicles in Oebalus ypsilongriseus De Geer, 1773 (Araújo et al. 2020) demonstrates that differences concerning the number of follicles occur even within the same genus, and therefore, does not seem to be a potential character for the identification at taxonomic levels above genus.

Of nineteen revised Pentatomidae species, including the three studied here, seventeen exhibited a peritoneal sheath covering the testes and part of deferent ducts with a red tinge (Pendergrast 1956, 
Lemos et al. 2005, Kaur \& Patial 2012, Ozyurt et al. 2013a, 2014, 2015, Jyoti et al. 2015, Araújo et al. 2020), whereas only two species $-N$. viridula (Esquivel et al. 2009) and Thyanta perditor Fabricius, 1794 (Araújo et al. 2020) - exhibited a yellow-orange peritoneal sheath. The basal region of deferent ducts with a yellowish color in $P$. guildinii is one of the major anatomical differences between the studied species. The color of the peritoneal sheath does not follow a pattern among Hemiptera (Gomes et al. 2013). However, the sheath is transparent in the studied aquatic Heteroptera families (Castanhole et al. 2008, 2010; Munhoz et al. 2020), as occurs in the subfamily Triatominae (Alevi et al. 2014). Lipophorin is one of the major insect lipoproteins (Van Hoof et al. 2005), particularly involved in lipid transport from absorption or synthesis to storage and uptake, such as the fat body, ovary, and testis (Jung \& Yun 2007). Differences in diet and metabolism may be related to differences in pigment color of the peritoneal sheath of the reproductive tract.

Elongated testes have also been described for the pentatomids Tropicoris punctipes Stål, 1876, Erthesina fullo Thurnberg, 1783 (Kaur \& Patial 2012), and T. perditor (Araújo et al. 2020). Among Pentatomidae, species can have elongated-ovoid (Esquivel et al. 2009, Kaur \& Patial 2012, Ozyurt et al. 2013a, Araújo et al. 2020), cylindrical (Ozyurt et al. 2014), and kidney-shaped testes (Jyoti et al. 2015). The shape of testicles highly varies among Pentatomidae. However, this characteristic is conserved at the species level and may be a character of taxonomic potential.

In most Pentatomidae, spermatozoa migrate from the testes after spermatogenesis and are stored along the deferent ducts (Kaur \& Patial 2012, 2016, Araújo et al. 2020), which was observed in the three studied species. The presence of a seminal vesicle has been described in some pentatomid species, $N$. virdula Pendergrast, 1956 and Brachymena cincta Fieber, 1861 (Abbasi 1973), Dolycoris indicus Stål, 1876 (Santos et al. 2003), and E. ventralis (Ozyurt et al 2015). Testis follicles with gem cells at different stages of spermatogenesis suggest that the species studied here have continuous spermatozoa production, which may allow multiple mating during adulthood, as reported in other Hemiptera (Moreira et al. 2008).

The anatomy of female reproductive tracts of $O$. insularis, $C$. ubica, and $P$. guildinii is similar to what has already been described in other Heteroptera (Kumar 1962, Pericart 1972, Lis 2003, Lemos et al. 2005, Ozyurt et al. 2013b). In mature female adults, oocyte development was observed probably due to vitellogenin availability in the hemolymph (Raikhel \& Dhadialla 1992, Nijhout 1998, Fortes et al. 2011). The development pattern of ovarioles is different among Hemiptera species; however, it is synchronous in the three species studied here, as well as in Porphyrophora polonica Linnaeus, 1858 (Szklarzewicz 1998), Steingelia gorodetskia Nasonov, 1908 (Koteja et al. 2003), and in Graphosoma lineatum Linnaeus, 1758 (Ozyurt et al. 2013b); on the other hand, it is asynchronous in Gossyparia spuria Modeer, 1778 (Szklarzewicz 1998) and Dactylopius coccus Costa, 1835 (Ramírez-Cruz et al. 2008).

The units forming Heteroptera ovarioles generally consist of a terminal filament, tropharium, vitellarium, and pedicel (Davey 1958, 1959, Davey \& Webster 1967, Ma \& Ramaswamy 1987, Nijhout 1998, Szklarzewicz 1998, Lemos et al. 2005, Jahnke et al. 2006, Ozyurt 2013b). However, the number of ovarioles can vary even intraspecifically in response to reproductive strategy, seasonality, or resource availability (Wellings et al. 1980, Tschinkel 1987, Stewart et al. 1991).
Seven ovarioles were observed In O. insularis, C. ubica, and $P$. guildinii while this number varies from 8 to 14 in most Heteroptera (Grozeva \& Kuznetsova 1992, Bunig 1994, Lalitha et al. 1997, Lis 2003, Jahnke et al. 2006, Ogorzalek 2007, 2009, Ozyrt et al. 2013b). However, approximately 100 ovarioles have been observed in Palaecoccus fuscipennis (Szklarzewicz et al. 2005), 300 have been observed in P. polonica (Szklarzewicz 1998), and 400 have been observed in Dysmicoccus coccus (Ramírez-Cruz et al. 2008).

Females of $P$. guildinii lay an egg mass that ranges from 3 to 37 eggs (Panizzi et al 2000), similar to that observed in figures 4d-e from the present study, which indicates an approximate load of 42 eggs. Zachrisson et al (2014) demonstrated that $O$. insularis can deposit masses containing 17 to 24 eggs, yet figures $2 \mathrm{e}-\mathrm{g}$ in the present study show a laying potential of up to 56 eggs in a short period. For this reason, the number of eggs deposited may depend primarily on the type of host plant, food quality, and defensive behavior against natural enemies (Panizzi et al 2000, Panizzi \& Silva 2012, Zachrisson et al 2014).

The spermatheca is a structure typically present in the reproductive tract of female heteropterans, and is responsible for storing and maintaining viable spermatozoa until oocyte fertilization (Pendergrast 1957, Singh 1968, Kumar 1969a, 1969b; Ahmad \& McPherson 1998, Rider \& Chapin 1991). Interspecific variations in size, spermathecal shape, and number of associated glands are important characters for the systematics of this group (Kumar 1971, Rider \& Chapin 1991, Ahmad \& McPherson 1998, Candan et al. 2015). The spermathecas in the three species studied have different shapes and coloration, similar to $O$. insularis, in which this organ is quite developed with an evident spermathecal duct.

According to Panizzi \& Silva (2012) the longevity of females from several stink bug species, including P. guildinii and C. ubica, is sharply reduced according to the reproductive behavior associated with sexual activity and copulation. This finding shows how data on reproductive morphophysiology can provide important information for strategies aiming at population control of pest insects.

Reproductive parameters of pentatomids can be affected by growthregulating insecticides (Castro et al. 2012) via chemical communication, e.g. pheromones (McBrien \& Millar 1999), and substrate vibrations (Laumann et al. 2018). These control alternatives should be monitored and analyzed through possible morphological changes in the reproductive tracts of female and male stink bugs.

The reproductive tract anatomy of female and male $O$. insularis, C. ubica and $P$. guildinii stink bugs in this study were described as the major characters that differentiate these species, as is the size of the testes and deferent ducts, and insertion sites of the accessory glands. The morphology of the reproductive tract generates important characters that can contribute to elucidate reproductive strategies as useful tools in agricultural pest management plans.

\section{Acknowledgements}

The authors thank Dr. Joseph Eger, Dow AgroSciences, Tampa, Florida, for the kindness and immediate assistance with confirmation in identifying all stink bug species. 


\section{Authors' Contributions}

Vinícius Albano Araújo: Substantial contribution in the concept and design of the study. Contribution to data collection; Contribution to data analysis and interpretation; Contribution to manuscript preparation. Contribution to critical revision, adding intellectual content.

Tito Bacca: Substantial contribution in the concept and design of the study; Contribution to data collection; Contribution to critical revision, adding intellectual content.

Lucimar Gomes Dias: Substantial contribution in the concept and design of the study; Contribution to data collection; Contribution to critical revision, adding intellectual content.

\section{Conflict of interest}

The authors declare that they have no conflict of interest related to the publication of this manuscript.

\section{Data availability}

All data are presented in the results section.

\section{References}

ABBASI, Q.T. 1973. Functional morphology of the male and female reproductive organs of some Pentatomomorphous bugs (Hemiptera; Heteroptera) of Pakistan with references to their karyotypes and their bearing on classification. Ph. D. Thesis, University of Karachi, Karachi.

ADAMS, T.S. 2001. Morphology of the internal reproductive system of the male and female two-spotted stink bug, Perillus bioculatus (F.) (Heteroptera: Pentatomidae) and the transfer of products during mating. Invertebr. Reprod. Dev. 39(1):45-53.

AHMAD, I. \& McPHERSON, J.E. 1998. Additional information on male and female genitalia of Parabrochymena Larivihre and Brochymena Amyot \& Sewille (Hemiptera: Pentatomidae). Ann. Entomol. Soc. Amer. 91:800-807.

ALEVI, K.C.C., OLIVEIRA, J., ROSA, J.A. \& AZEREDO-OLIVEIRA, M.T.V. 2014. Coloração da bainha peritoneal testicular como uma sinapomorfia dos triatomíneos (Hemiptera, Reduviidae). Biota Neotropica. 14(4):e20140099. http://dx.doi.org/10.1590/1676-06032014009914 (last acess on 15/07/2020).

ARAÚJO, V.A., LINO-NETO, J., RAMALHO, F.S., ZANUNCIO, J.C. \& SERRÃO, J.E. 2011. Ultrastructure and heteromoprphism of spermatozoa in five species of bugs (Pentatomidae: Heteroptera). Micron. 42(6):560-671.

ARAÚJO, V.A., OLIVEIRA, M.S., CORTES, I.C.H., VITERI-D, J. \& DIAS, L.G. 2020. Morphology of the male reproductive tract in two species of phytophagous bugs (Pentatomidae: Heteroptera). J. Entomol. Zool. Stud. 8(2):1608-1614.

BONHAG, P.F. 1958. Ovarian structure and vitellogenesis in insects. Annu. Rev. Entomol. 3:137-160.

BUNING, J. 1994. The ovary of Ectognatha. In The insect ovary: ultrastructure, previtellogenic growth and evolution (J. Büning, ed). Chapman \& Hall, London.

CANDAN, S., ERBEY, M. \& YILMAZ, S.Y. 2010. Morphology of the spermatheca of Dolycoris baccarum (Linnaeus, 1758) (Heteroptera: Pentatomidae). Entomol. News. 121(4):334-341.

CANDAN, S., ERBEY, M., ÖZYURT, N. \& SUlUdERE, Z. 2014. Spermathecae morphology in four species of Eurydema Laporte, 1833 (Heteroptera: Pentatomidae) from Turkey: A Scanning Electron Microscope Study. J. Entomol. Zool. Stud. 2(3):206-213.

CANDAN, S., ZULUDERE, Z., YILMAZ, S.Y. \& ERBEY, M. 2015. Morphology of spermathecae of some pentatomids (Hemiptera: Heteroptera: Pentatomidae) from Turkey. Zootaxa. 3937(3):500-516.
CASTANHOLE, M.M.U., PEREIRA, L.L.V., SOUZA, H.V., BICUDA, H.E.M.C., COSTA, L.A.A. \& ITOYAMA, M.M. 2008. Heteropicnotic chromatin and nucleolar activity in meiosis and spermiogenesis of Limnogonus aduncus (Heteroptera, Gerridae): a stained nucleolar organizing region that can serve as a model for studying chromosome behavior. Genet. Mol. Res. 7(4):1398-1407

CASTANHOLE, M.M.U., PEREIRA, L.L.V., SOUZA, H.V. \& ITOYAMA, M.M. 2010. Spermatogenesis and karyotypes of three species of water striders (Gerridae, Heteroptera). Genet. Mol. Res. 9(3):1343-1356.

CASTRO, A. A., LACERDA, M. C., ZANUNCIO, T. V., RAMALHO, F. D. S., POLANCZYK, R. A., SERRÃO, J. E. \& ZANUNCIO, J. C. 2012. Effect of the insect growth regulator diflubenzuron on the predator Podisus nigrispinus (Heteroptera: Pentatomidae). Ecotoxicology. 21(1):96-103.

CREMONEZ, P.S.G., PINHEIRO, D.O., FALLEIROS, A.M.F. \& NEVES, P.M.O. 2017. Performance of reproductive system of Dichelops melacanthus (Hemiptera: Pentatomidae) subjected to buprofezin and priproxyfen: morphological analysis of ovarioles and testes. Semina: Ciênc. Agrár. 38(4):2279-2292.

DAVEY, K.G. 1958. The migration of spermatozoa in the female of Rhodnius prolixus Stål. J. Exp. Biol. 35:694-701.

DAVEY, K.G. 1959. Spermatophore production in Rhodnius prolixus (Hemiptera: Triatomidae). Q. J. Microsc. Sci. 100(2):221-230.

DAVEY, K.G. \& WEBSTER, G.F. 1967. The structure and secretion of the spermatheca of Rhodnius prolixus Stil. A histochemical study. Can. J. Zool. 45:653-657.

ESQUIVEL, J.F. 2009. Stages of gonadal development of the southern green stink bug (Hemiptera: Pentatomidae): improved visualization. Ann. Entomol. Soc. Am. 102(2):303-309.

FORTES, P., SALVADOR, G. \& CÔNSOLI, F.L. 2011. Ovary development and maturation in Nezara viridula (L.) (Hemiptera: Pentatomidae). Neotrop. Entomol. 40(1):89-96.

GALILEO, M. \& HEINRICHS, E. 1978. Efeito dos danos causados por Piezodorus guildinii (Westwood, 1837) (Hemiptera: Pentatomidae), em diferentes níveis e épocas de infestação no rendimento de grãos de soja Glycine $\max$ (L.) Merrill. An. Soc. Entomol. Bras. 7(1):20-25.

GOMES, M.O., CASTANHOLE, M.M.U., SOUZA, H.V., MURAKAMI, A.S., FIRMINO, T.S.S., SARAN, P.S., BANHO, C.A., MONTEIRO, L.S., SILVA, J.C.P., ITOYAMA, M.M. 2013. Morphological aspects of the testes of 18 species of terrestrial of Heteroptera from Northwestern São Paulo (Brazil). Biota Neotropica. 13(3):131-135. https://doi.org/10.1590/S167606032013000300016 (last acess on 13/07/2020).

GRAZIA, J., CAVICHIOLI, R.R., WOLFF, V.R.S., FERNANDES, J.A.M. \& TAKIYA, D.M. 2012. Hemiptera. In Insetos do Brasil: Diversidade e Taxonomia (J.A. RAFAEL., G.A.R. MELO., C.J.B., CARVALHO., A.S., CASARI. \& R. CONSTANTINO, eds). Holos Editora, Ribeirão Preto, p.347-406.

GRAZIA, J., PANIZZI, A. R., GREVE, C., SCHWERTNER, C.F., CAMPOS, L.A., GARBELOTTO, T. A. \& FERNANDES, J.A.M. 2015. Stink bugs (Pentatomidae). In True bugs (Heteroptera) of the neotropics (A.R. Panizzi \& J. Grazia, eds). Springer, Dordrecht, Netherlands, p.681-756.

GROZEVA, S.M. \& KUZNETSOVA, V.G. 1992. The reproductive system of some bug families (Heteroptera, Pentatomomorpha). In Advances in Regulation of Insect reproduction (B. Bennettová., I. Gelbič \& T. Soldán, eds). Institute of Entomology, Czech Acad. Sci., p.97-102.

GUTIÉRREZ, A., ARIAS, E., GARCÍA, A. \& CORONA, R. 1985. Evaluación del nivel de daño causado por diferentes índices de población de $O$. insularis en el cultivo de arroz. Ciência Técnica Agrícola 8(1): 63-74.

JAHNKE, S.M., REDAELLI, L.R. \& DIEFENBACH, L.M.G. 2006. Internal reproductive organs of Cosmoclopius nigroannulatus (Hemiptera: Reduviidae). Braz. J. Biol. 66(2A):509-512.

JYOTI, G., SANTOS, N. \& ASHOK, D. 2015. Revamp studies on morphohistology of the male reproductive system of Halys dentatus Fabricious (Hemiptera: Pentatomidae). Ann. Res. Rev. Biol. 63(3):176-183. 
JUNG, E.S. \& YUN, H.K. 2007. Receptor-mediated endocytosis of lipid and lipophorin by the larval fat body, adult ovary and testis in the wax moth Galleria mellonella. Entomol. Res. 37(1):60-65.

KARBAN, R. \& AGRAWAL, A.A. 2002. Herbivore offense. Annu. Rev. Ecol. Syst. 33:641-64.

KAUR, H. \& PATIAL, N. 2012. Internal male reproductive organs of ten species of Heteroptera (Insecta: Hemiptera). Indian J. Fund. App. Life Sci. 2(1):317-324.

KAUR, H. \& PATIAL, N. 2016. Internal male reproductive organs in five species of Heteroptera (Insecta: Hemiptera). Indian J. Fund. App. Life Sci. 6(3):30-35

KOTEJA,J., PYKA-FOŚCIAK, G., VOGELGESANG, M. \& SZKLARZEWICZ, T. 2003. Structure of the ovary in Steingelia (Sternorryncha:Coccinea), and its phylogenetic implications. Arthr. Struct. Dev. 32:247-256.

KUMAR, R. 1962. Morphotaxonomical studies on the genetalia and salivary glands of some Pentatomoidea. Entomol. Tidskr. 83:44-88.

KUMAR, R. 1969a. Morphology and relationships of the Pentatomoidea (Heteroptera): III, Natalicolinae

and some Tessaratomidae of uncertain position. Ann. Entomol. Soc. Amer. 62:681-695

KUMAR, R. 1969b. Morphology and relationships of the Pentatomoidea (Heteroptera) IV. Oncomerinae (Tessaratomidae). Aust. J. Sci. 17:553-606.

KUMAR, R. 1971. Morphology and relationships of the Pentatomidae (Heteroptera) V. Urostylidae. Amer. Midland Naturalist. 85:63-73.

LALITHA, T.G., SHYAMASUNDARI, K. \& RAO, K.H. 1997. Morphology and histology of the female reproductive system of Abedus ovatus Stål (Belostomatidae: Hemiptera: Insecta). Mem. Inst. Oswaldo Cruz. 92:129135 .

LAUMANN, R.A., MACCAGNAN, D.H.B., ČOKL, A., BLASSIOLIMORAES, M.C. \& BORGES, M. 2018. Substrate-borne vibrations disrupt the mating behaviors of the neotropical brown stink bug, Euschistus heros: implications for pest management. J. Pest Sci. 91(3):995-1004.

LEMOS, W.P., MEDEIROS, R.S., RAMALHO, F.S. \& ZANUNCIO, J.C. 2001. Effects of plant feeding on the development, survival, and reproduction of Podisus nigrispinus (Dallas) (Heteroptera, Pentatomidae). Int. J. Pest Manage. 27(2):89-93.

LEMOS, W.P., SERRÃO, J.E., RAMLHO, F.S., COLA-ZANUNCIO, J.C., ZANUNCIO. J.C. \& LACERDA, M.C. 2005. Effect of diet on male reproductive tract of Podisus nigrispinus (Dallas) (Heteroptera: Pentatomidae). Braz. J. Biol. 65(1):91-96.

LI, H., LEAVENGOOD-JR, J.M., CHAPMAN, E.G., BURKHARDT, D., SONG, F., JIANG, P., LIU, J., ZHOU, X. \& CAI, W. 2017. Mitochondrial phylogenomics of Hemiptera reveals adaptive innovations driving the diversification of true bugs. P. Roy. Soc. B-Biol. Sci. 284(1862): 20171223.

LIS, J.Z. 2003. Ovaries and lateral oviducts of the female internal reproductive system in five species of burrower bugs (Hemiptera: Heteroptera: Cydnidae). Polish J. Entomol. 72:305-312.

LUCINI, A.R., PANIZZI, M.A., SILVA, M.A. \& MARSARO, A.L. 2020. Performance and preference o Chinavia erythrocnemis (Berg) (Heteroptera: Pentatomidae) on reproductive structures of cultivated plants. Neotrop. Entomol. 49:163-17.

MA, W.K. \& Ramaswamy, S.B. 1987. Histological changes during ovarian maturation in the tarnished plant bug, Lycus lineolaris (Hemiptera: Miridae). Int. J. Insect Morphol. Embryol. 16(5/6):309-322.

McBRIEN, H. L. \& MILLAR, J. G. 1999. Phytophagous bugs. In Pheromones of non-lepidopteran insects associated with agricultural plants (J. HARDIE \& A. K. MINKS, eds). CABI Publishing, Wallingfod, p.277-304.

McPHERSON, J.E. \& McPHERSON, R.M. 2000. Stink bugs of economic importance in America North of Mexico. CRC Press, Florida, USA.

MOREIRA, P.A., ARAÚJO, V.A., ZAMA, U. \& LINO-NETO, J. 2008. Morphology of male reproductive system in three species of Trypoxylon (Trypargilum) Richards (Hymenoptera: Crabronidae). Neotrop. Entomol. 37(4):429-435.
MUNHOZ, I.L.A., SERRÃO, J.E., DIAS, G., LINO-NETO, J., MELO, A.L. \& ARAÚJO, V.A. 2020. Anatomy and histology of the male reproductive tract in giant water bugs of the genus Belostoma Latreille, 1807 (Heteroptera, Belostomatidae). Int. J. Trop. Insect Sci. 40(2):1608-1614.

NIJHOUT, H.F. 1998. Reproduction. In Insect hormone (H.F. Nijhout, ed). Princeton: Princeton University, Nova Jersey, USA, p.142-159.

OGORZALEK, A. 2007. Structural and functional diversification of follicular epithelium in Coreus marginatus (Coreidae: Heteroptera). Arth. Struct. Dev. 36:209-219.

OGORZALEK, A. \& TROCHIMCZUK, A. 2009. Ovary structure in a presocial insect, Elasmucha grisea (Heteroptera, Acanthosomatidae). Arth. Struct. Dev. 38(6):509-519.

ÖZYURT, N., CANDAN, S. \& SULUDERE, Z. 2013a. The morphology and histology of the male reproductive system in Dolycoris baccarum Linnaeus 1758 (Heteroptera: Pentatomidae) - Light and scanning electron micoscope studies. Micron. 44(1):101-106.

ÖZYURT, N., CANDAN, S., SULUDERE, Z. \& AMUTKAN, D. 2013b. Morphology and histology of the male reproductive system in Graphosoma lineatum (Heteroptera: Pentatomidae) based on optical and scanning electron microscopy. J. Entomol. Zool. Stud. 1(4):40-46.

ÖZYURT, N., CANDAN, S. \& SULUDERE, Z. 2014. The morphology and histology of the male reproductive system in Apodiphus amygdali (Germar,1817) (Heteroptera: Pentatomidae). Life: The Excitement of Biology. 2(1):31-41.

ÖZYURT, N., CANDAN, S. \& SULUDERE, Z. 2015. Ultrastructure of male reproductive system of Eurydema ventrale Kolenati 1846 (Heteroptera: Pentatomidae). Microsc. Res. Techniq. 78(8):643-653.

PANIZZI, A. R. \& SILVA, F. A. 2012. Seed-sucking bugs (Heteroptera). In Insect bioecology and nutrition for integrated pest management (A. R. PANIZZI \& J. R. PARRA, eds). CRC Press, Boca Raton. p.295-324.

PANIZZI, A. R., McPHERSON, J.E., JAMES, D.G., JAVAHERY, M. \& McPHERSON, R.M. 2000. Stink bugs (Pentatomidae). Heteroptera of Economic Importance. CRC Press, Boca Raton. p.421-474.

PANIZZI, A. R. \& SLANSKY, F. 1985. Review of phytophagous pentatomids (Hemiptera: Pentatomidae) associated with soybean in the Americas. Fla. Entomol. 68:184-214.

PENDERGRAST, J.G. 1956. The male reproductive organs of Nezara viridula with a preliminary account of their development (Heteroptera, Pentatomidae). Trans. Roy. Soc. New Zeal. 84(1):139-146.

PERICART, J. 1972. Hemipteres Anthocorida, Ciicidae et Microphysidae de I'Ouest-Palearctique. Faune de I'Europe et du Bassin Mediterraneen, 7:1-402.

POSSEBOM, T., LUCINI, T., PANIZZI, A.R. 2020. Stink bugs nymph and adult biology and adult preference on cultivated crop plants in the southern brazilian Neotropics. Environ. Entomol. 49(1):132-140.

R Core Team (2016) R: A Language and Environment for Statistical Computing. R Foundation for Statistical Computing, Vienna, Austria.

RAMÍREZ-CRUZ, A., LLANDERAL-CÁZARES, C. \& RACOTTA R. 2008. Ovariole structure of the cochineal scale insect, Dactylopius coccus. J. Insect Sci. 8:1-5.

RAIKHEL, A.S. \& DHADIALLA, T.S. 1992. Accumulation of yolk proteins in insect oocyte. Annu Rev Entomol. 37:217-251.

RIDER, D.A. \& CHAPIN, J.B. 1991. Revision ofthe genus Thyanta Stål, 1862 (Heteroptera: Pentatomidae) South America. J. New York Entomol. Soc. 99:1-77.

RODRIGUES-AGNA, R.S., SERRÃO, J.E., TEIXEIRA, V.M., TORRES, J.B. \& TEIXEIRA, A. 2008. Spermatogenesis, changes in reproductive structures, and time constraint associated with insemination in Podisus nigrispinus. J. Insect Physiol. 54(12):1543-1551.

RODRIGUEZ, G.P., NAVAS, D., MEDIANERO, E. \& CHANG, R. 2006. Cuantificación del daño ocasionado por $O$. insularis (Heteroptera: Pentatomidae) en el cultivo de arroz (Oryzica-1) en Panamá. Rev. Colomb. Entomol. 32(2):131-135.

ROLSTON, L.H.A. 1983. Revision of the genus Acrosternum Fieber, subgenus Chinavia Orian, in the western hemisphere (Hemiptera: Pentatomidae). J. N. Y. Entomol. Soc. 91(2):97-176. 
SAILER, R.I. 1944. The genus Solubea (Heteroptera: Pentatomidae). Proc. Entomol. Soc. Was. 46(5):105- 27.

SANTOS, R.S.S., REDAELLI, L.R., DIEFENBACH, L.M.G., ROMANOWSKI, P. \& PRANDO, H.F. 2003. Characterization of the imaginal reproductive diapause of Oebalus poecilus (Hemiptera: Pentatomidae). Braz. J. Biol. 63(4):695-703.

SCHWERTNER, C.F. \& GRAZIA, J. 2007. O gênero Chinavia Orian (Hemiptera, Pentatomidae, Pentatominae) no Brasil, com chave pictórica para os adultos. Rev. Bras. Entomol. 51(4):416-435.

SILVA, C.C., LAUMANN, R.A., MORAES, M.C.B., AQUINO, M.F.S. \& BORGES, M. 2015. Comparative biology of two congeneric stinkbugs, Chinavia impicticornis and C. ubica (Hemiptera: Pentatomidae). Pesqui. Agropecu. Bras. 50(5):355-362.

SINGH, M.P. 1968. Female reproductive organs and their development in Chryscoris stolli Wolff (Heteroptera: Pentatomidae). B. Entomol. 9(1):25-35.

SMANIOTTO, L.F. \& A.R. PANIZZI. 2015. Interactions of selected species of stink bugs (Hemiptera: Heteroptera: Pentatomidae) from leguminous crops with plants in the neotropics. Fla. Entomol. 98:7-17.

STEWART, L.A., HEMPTINNE, J.L. \& DIXON, A.F.G. 1991. Reproductive tactic of ladybird beetles: relationships between egg size, ovariole number and developmental time. Funct. Ecol. 5:380-385.
SZKLARZEWICZ, T. 1998. Structure of ovaries of scale insects. I. Pseudococcidae, Kermesidae, Eriococcidae, and Cryptococcidae (Insecta, Hemiptera, Coccinea). Int. J. Insect Morphol. Embryol. 27: 162-172.

SZKLARZEWICZ, T., KĈDRA, K. \& NIĪNIK, S. 2005. Ultrastructural studies of the ovary of Palaeococcus fuscipennis (Burmaister) (Insecta, Hemiptera, Coccinea: Monophlebidae). Folia Biol. 53: 45-50.

TSCHINKEL, W.R. 1987. Relationship between ovariole number and spermathecal sperm count in ant queens: a new allometry. Ann. Entomol. Soc. Am. 80:201-211.

VAN HOOF, D., RODENBURG, K.W. \& VAN DER HORST, D.J. 2005. Receptor-mediated endocytosis and intracellular trafficking of lipoproteins and transferrin in insect cells. Insect Biochem. Mol. Biol. 35:117-128.

WELLINGS, P.W., LEATHER, S.R. \& DIXON, A.F.G. 1980. Seasonal variation in reproductive potential: a programmed feature of aphid life cycles. J. Anim. Ecol. 49:975-985.

ZACHRISSON, B., POLANCO, P. \& MARTÍNEZ, O. 2014. Desempeño biológico y reproductivo de Oebalus insularis Stål (Hemiptera: Pentatomidae) en diferentes plantas hospedantes. Rev. Prot. Veg. 29(2):77-81.

Received: $21 / 05 / 2020$

Revised: 18/08/2020

Accepted: 20/08/2020

Published online: 18/09/2020 